\title{
Experimental Study of the Antitumor Activity of Polymetalacrylates against Animal Transplantable Tumors
}

\author{
Larisa A. Ostrovskaya ${ }^{1}$, M. G. Voronkov ${ }^{2}$, D. B. Korman ${ }^{1}$, M. M. Fomina ${ }^{1}$, N. V. Bluhterova ${ }^{1}$, V. A. \\ Rikova $^{1}$, K. A. Abzaeva ${ }^{2}$, L. V. Zhilitskaya ${ }^{2}$ \\ ${ }^{1}$ N.M. Emanuel Institute of Biochemical Physics, Russian Academy of Sciences, Russian, Moscow; ${ }^{2}$ A.E. Favorsky Irkutsk Institute \\ of Chemistry, Siberian Branch of the Russian Academy of Sciences, Irkutsk, Russia. \\ Email: larros@list.ru
}

Received February $25^{\text {th }}, 2010$; revised April 10 ${ }^{\text {th }}, 2010$; accepted May $28^{\text {th }}, 2010$.

\begin{abstract}
The antitumor activity of the fourteen polymetalacrylates against two models of murine solid tumors (Lewis lung carcinoma and Acatol adenocarcinoma) as well as the acute toxicity of these compounds has been studied. It was shown that polyacrylates of noble metals (argent, aurum, platinum), namely argacryl $(M=A g)$, auracryl $(M=A u)$ and platacryl $(M=P t)$ were the most effective agents among tested compounds against studied tumors. Thus, the tumor growth inhibitory effect of argacryl against Lewis lung carcinoma was equal to $90 \%$, the life-span of treated by this compound animals has increased on $50 \%$ in comparison with control. Auracryl induced the inhibition of the Lewis lung carcinoma and Acatol adenocarcinoma development on 60 and 65\%, correspondingly and the increasing of the mean life-span of animals with Lewis lung carcinoma on $20 \%$ in comparison with control. Platacryl inhibited the growth of Lewis lung carcinoma on $40 \%$ increasing the mean life-span of animals on $25 \%$ in comparison with control. In this way it was established that argacryl is the agent with the strongest antitumor activity among studied polymetalacrylates. On the basis of obtained data it seems possible to consider polymetalacrylates as a group of agents with the potential antitumor activity suitable for the further deep experimental investigation.
\end{abstract}

Keywords: Polymetalcrylates, Antitumor Activity, Transplantable Tumors of Animals

\section{Introduction}

The development of drugs capable of inhibiting the growth of a malignant tumor at the expense of the influence on its blood supply is one of recognized areas in the field of biomedical chemistry and experimental oncology. Modern approaches to the solution of this problem are based on the investigation of medicines causing regional embolism of vessels, feeding a tumor, or creation of drugs inhibiting neo-angiogenesis processes in tumor. Over 500 various chemical compounds possessing an anti-angiogenesis activity against some experimental models are known at the present time [1].

In this field, the metal derivatives of polyacrylic acid (polymetalacrylates) are especially promising [2-9].

A pharmacological mechanism of action of polymetalacrylates is based first of all on their unusual influence on a coagulating system of blood leading to the formation of interpolymers with blood plasma proteins $[10,11]$.
The first representative of medicines of this type, feracryl, is allowed for a broad medical use in Russia as a blood-stopping agent [12-16]. Argacryl (an incomplete silver salt of polyacrylic asid) is later offered as an effective hemostatic with a broad spectrum of pharmacological properties [2-4]. Silver containing medicines (poviargol, protargol, kollargol, argovit etc.) are successfully used in medical practice as antiseptic remedies actively suppressing a pathogenic flora and simultaneously stimulating an immune status [17].

It is well known that drugs containing complexes of metals of platinum group (cisplatin, carboplatin et al.) are one of the most commonly used cytostatics in the modern antitumor chemotherapy [1,18-20].

Metallic derivatives of polyacrylic acid were not previously tested as antitumor agents.

The aim of our research has been the study of the antitumor activity of polymetalacrylate derivatives containing in their structure different metals (PMA) for the 
reveal of the most effective compounds interesting for a further deep experimental investigation.

\section{Materials and Methods}

\subsection{Compounds}

The fourteen metal derivatives of polyacrylic acid have been studied in the biological experiment. These incomplete metallic salts of polyacrylic acid containing metal ions (Table 1) correspond to the general formula $\left(-\mathrm{CH}_{2}-\mathrm{CH}-\mathrm{COOH}\right)_{\mathrm{n}}\left(-\mathrm{CH}_{2}-\mathrm{CH}-\mathrm{COOM}\right)_{\mathrm{m}}$, where $n=1200-$ $3500 ; m=1650-6650$ and contain $4-8$ mass $\%$ of a metal are colorless or colored films. They have been synthesized by the method of polymer analogous transformations of polyacrylic acid by organic and inorganic metal salts [2-9]. The molecular weight of these polymetalacrylates are in the range from 1000000 to $3000000 \mathrm{D}$. Absorbtion bands $1548-1540 \mathrm{~cm}^{-1}\left(v_{\text {as }} \mathrm{COO}^{-}\right)$и $1405-$ $1410 \mathrm{~cm}^{-1}\left(v_{\mathrm{s}} \mathrm{COO}^{-}\right) ; 1694-1649 \mathrm{~cm}^{-1}(\mathrm{COOH})$, a widened band in the region 3420-2554 $\mathrm{cm}^{-1}$, shifted in a lowfrequency field (associated $\mathrm{OH}$ ).

Compounds prepared on the ground of PMA were used as aqueous solutions injected intraperitoneally (i/p) to experimental animals $(0.2-0.8 \mathrm{ml})$. Under the identifycation of parameters of the acute toxicity - the mean lethal dose result to the death of $50 \%$ of animals $\left(\mathrm{LD}_{50}\right)$ and the maximum tolerated dose not causing the death of any mice (MTD)-agents were injected one time, i/p, in the wide range of doses (from 10 to $200 \mathrm{mg} / \mathrm{kg}$ ).

For the estimation of the antitumor effect, compounds were injected $\mathrm{i} / \mathrm{p}$, five times, every day starting from the next day after tumor transplantation. Daily doses for the most of agents were closed to $1 / 5$ from MTD, but the ones for polyacrylates of noble metals (argacryl, auracryl and platacryl) were closed to 1/10 from MTD.

\subsection{Laboratory Animals}

Experiments have been carried out on 400 inbred mice $\mathrm{BDF}_{1}$-first generation hybrids $\mathrm{f}_{1}\left(\mathrm{DBA}_{2} \times \mathrm{C}_{57} \mathrm{Bl} / 6\right)$ and $\mathrm{Balb} / \mathrm{c}$, males with the body weight of 18-20 g (Nursery "Stolbovaya" of the Russian Academy of Medical Sciences). The animals feeding regimen was based on the usage of the standard certificated commercial dry extruded food for rodents (PK-120-1) [21].

\subsection{Experimental Models}

Solid tumors, such as Lewis lung carcinoma and Acatol adenocarcinoma have been used as experimental testsystems. The transplantation of tumors has been done according to the standard procedures, subcutaneously at the right flank of mice by fragments of a tumor tissue suspended in a physiological solution of sodium chloride. The size of the inoculation material was equal to $0.3 \mathrm{ml}$ [21].

\subsection{The Antitumor Activity Test}

Kinetics of the tumor growth in groups of treated $(\mathrm{T})$ and control (C) animals as well as duration of mice life-span in both groups were studied. The coefficient of the tumor growth inhibition (TGI, \%) and the increasing of the mean life-span $(\Delta \tau, \%)$ of treated animals in compare with control were the indicators of the antitumor activity of tested drugs. The TGI coefficient has been determined according to the correlation: TGI $=\left(\mathbf{P}_{\mathbf{C}}-\mathbf{P}_{\mathrm{T}}\right) / \mathbf{P}_{\mathbf{C}} \%$, where $\mathbf{P}_{\mathbf{C}}$ and $\mathbf{P}_{\mathbf{T}}$ are volumes (or weights) of tumor in the control group and group of treated animals, accordingly. Two mutually perpendicular sizes of the tumor node were measured over the whole period of tumors development for the study of the kinetics of the tumor growth. The tumor volume was measured according to the formula for an ellipsoid as $\mathbf{V}=\mathbf{a} \mathbf{b}^{\mathbf{2}} / \mathbf{2}$, where $\mathbf{a}$ is the length, b is the width and height of a tumor. The tumor weight corresponds to its volume, since the density of a tumor tissue is generally agreed to be equal to $1 \mathrm{~g} / \mathrm{cm}^{3}$ [21].The increasing of the mean life-span $(\Delta \tau, \%)$ of treated animals in comparison with the control was evaluated as $\Delta \tau$ $=\left(\tau_{\mathbf{C}}-\tau_{\mathbf{T}}\right) / \tau_{\mathbf{C}}, \%$, where $\tau_{\mathbf{C}}$ and $\tau_{\mathbf{T}}$ are the mean life-span of control and treated animals, accordingly.It is assumed to consider as minimal significant the value of TGI coefficient equal to $50 \%$ as well as the value of the increasing of the mean life-span $(\Delta \tau)$ of treated animals in comparison with the control equal to $25 \%$ [21]. In accordance with the standard recommendations each group of treated and control animals comprised six and eight mice, correspondingly [21]. Experiments were repeated two or three times. The results of the main experiments are represented as kinetic curves of the tumor growth in groups of treated and control animals. Each dot on these curves presents the mean value of the tumor weight for 12-18 mice.

Experimental animals were observed during the whole period of the development of tumors.

Computer program "Statistics 6.0" was used for the statistical analysis of experimental data. F-criterion significance test was used for the estimation of the confidence of difference between mean values of tumor weight in groups of treated and control animals. It is consider that difference between values of tumor weight in groups of treated and control animals is confidence if the estimated value " $F$ " is more than the value of "F-criterion" known for prescribed level of significance and for the certain degrees of freedom $\left(f_{1} ; f_{2}\right)$ [22].

\section{Results}

The fourteen polimetalacrylates (PMA) including four compounds containing noble metals, such as silver, gold, platinum, palladium, have been studied in biological experiments. Acute toxicity of PMA has been defined. The antitumor activity of compounds against Lewis lung car- 
cinoma and Acatol adenocarcinoma has been established.

\subsection{Toxicity}

All studied compounds have a good solubility in water (excluding poorly soluble palladacryl).

When studying the compounds acute toxicity it has been established that PMA $\mathrm{LD}_{50}$ values vary within the limits from 15 to $200 \mathrm{mg} / \mathrm{kg}$, while values of MTD vary in diapasons from 10 to $150 \mathrm{mg} / \mathrm{kg}$ depending from the nature of the metal $(\mathrm{M})$.

From the data indicated in the Table 1 it follows that auracryl $(\mathrm{M}=\mathrm{Au})$ and feracryl $(\mathrm{M}=\mathrm{Fe})$ have a lower order toxicity than the other studied polymetalacrylates. $\mathrm{LD}_{50}$ and MTD for auracryl were equal to such values, as 150 and $100 \mathrm{mg} / \mathrm{kg}$, the same ones for feracryl were equal to 200 and $150 \mathrm{mg} / \mathrm{kg}$ correspondingly. The same indicators for two other derivatives containing noble metals-platacryl $(\mathrm{M}=\mathrm{Pt})$ and $\operatorname{argacryl}(\mathrm{M}=\mathrm{Ag})$ were equal to $75 ; 50 \mathrm{mg} / \mathrm{kg}$ and $25 ; 20 \mathrm{mg} / \mathrm{kg}$ respectively (Table 1).

The values of the $\mathrm{LD}_{50}$ for the other ten compounds were varied in the range from 15 till $50 \mathrm{mg} / \mathrm{kg}$. The values of the MTD for these compounds were varied in the range from 10 till $40 \mathrm{mg} / \mathrm{kg}$ (Table 1).

So as it is seen from the data represented in the Table 1 the most toxic agents between tested compounds were

Table 1. The acute toxicity of polymetalacrylates (the single $\mathrm{i} / \mathrm{p}$ administration of agents, $\mathrm{BDF}_{1}$ mice)

\begin{tabular}{ccccc}
\hline \# \# & PMA & Metal & $\begin{array}{c}\text { The maximum } \\
\text { tolerated dose } \\
\text { (MTD) } \\
\text { mg/kg }\end{array}$ & $\begin{array}{c}\text { The mean } \\
\text { lethal dose } \\
\text { (LD }_{\mathbf{5 0}} \text { (mg }\end{array}$ \\
\hline 1 & Liacryl & $\mathrm{Li}$ & 40 & 50 \\
2 & Rubacryl & $\mathrm{Rb}$ & 20 & 30 \\
3 & Cesacryl & $\mathrm{Cs}$ & 10 & 20 \\
4 & Licuacryl & $\mathrm{Li}+\mathrm{Cu}$ & 20 & 25 \\
5 & Mangacryl & $\mathrm{Mn}$ & 30 & 35 \\
6 & Feracryl & $\mathrm{Fe}$ & 150 & 200 \\
7 & Nicacryl & $\mathrm{Ni}$ & 10 & 15 \\
8 & Palladacryl & $\mathrm{Pd}$ & 10 & not defined \\
9 & Platacryl & $\mathrm{Pt}$ & 50 & 75 \\
10 & Argacryl & $\mathrm{Ag}$ & 20 & 25 \\
11 & Auracryl & $\mathrm{Au}$ & 100 & 150 \\
12 & Ziacryl & $\mathrm{Zn}$ & 15 & 20 \\
13 & Cadacryl & $\mathrm{Cd}$ & 30 & 35 \\
14 & Stanacryl & $\mathrm{Sn}$ & 10 & 15 \\
\hline
\end{tabular}

derivatives containing such metals as cesium (Cesacryl), nickel (Nicacryl), stannum (Stanacryl), while the less toxic one was the ferrum derivative (Feracryl).

\subsection{Antitumor Activity}

The antitumor activity of PMA against Lewis lung carcinoma and Acatol adenocarcinoma was tested.

The sensitivity of Lewis lung carcinoma to PMA compounds are characterized by data represented in Tables 2, 3 and on the Figure 1.

As it is seen from data below argacryl, auracryl and platacryl are the most effective among studied polymetalacrylates against this tumor model.

Thus, the tumor growth inhibitory effect of argacryl against Lewis lung carcinoma this tumor was equal to $90 \%$. The life-span of treated by argacryl animals has increased on $50 \%$ in comparison with control (Tables 2 , 3; Figure 1).

In case of auracryl the coefficient of the tumor growth inhibition was equal to $60 \%$ and the increase of the mean life-span of treated animals was $20 \%$ in comparison with control (Tables 2, 3; Figure 1).

Platacryl inhibits the growth of Lewis lung carcinoma on $40 \%$ increasing the mean life-span of treated animals on $25 \%$ in comparison with control (Tables 2, 3; Figure 1).

Asaturated aqueous solution of palladacryl containing less than $2 \%$ of palladium does not inhibit the growth of the tumor studied (Tables 2, 3).

It should be mentioned that some tested compounds such as cadacryl, rubacryl, feracryl induced the increasing of the mean life-span of treated mice with Lewis lung carcinoma on 53, 39 and $31 \%$ in compare to control correspondingly, but didn't influence on the rate of tumors growth (Tables 2, 3).

The obtained results prove that derivatives of noble metals $(\mathrm{M}=\mathrm{Ag}, \mathrm{Au}, \mathrm{Pt})$, espesially argacryl, are the most effective among studied polymetalacrylates against Lewis lung carcinoma.

The development of the other studied tumor - Acatol adenocarcinoma was the most effectively inhibited by auracryl - the value of the TGI coefficient for this agent was equal to $65 \%$ (Table 4, Figure 2).

Platacryl and argacryl inhibited the growth of Acatol adenocarcinoma on $55 \%$ and $50 \%$ in comparison with control, accordingly (Table 4, Figure 2).

Therefore, the results of these experiments prove that compounds argacryl, auracryl and platacryl pronounced the significant antitumor effect against some murine solid tumors such as Lewis lung carcinoma and Acatol adenocarcinoma.

The received data allows to consider polymetalacrylates as a new group of compounds with a potential antitumor activity. Antitumor effect of polymetalacrylates containing noble metals (Ag, Au, Pt) has been first estab- 


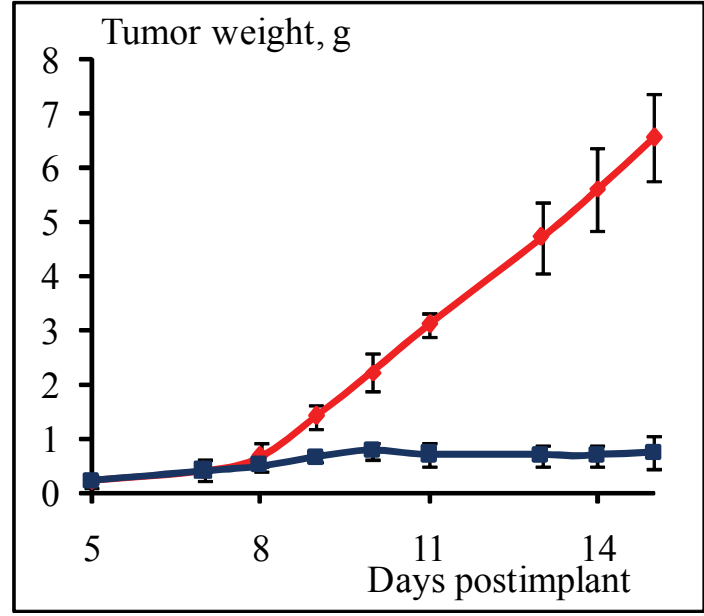

(a)

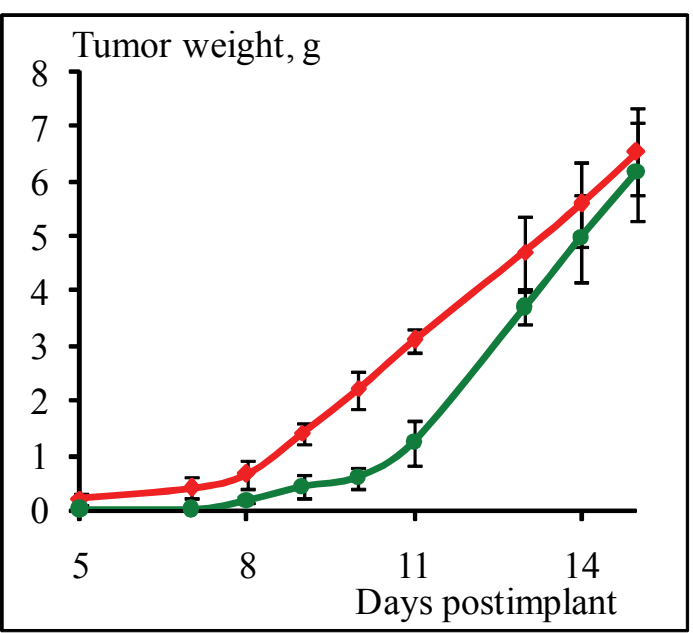

(b)

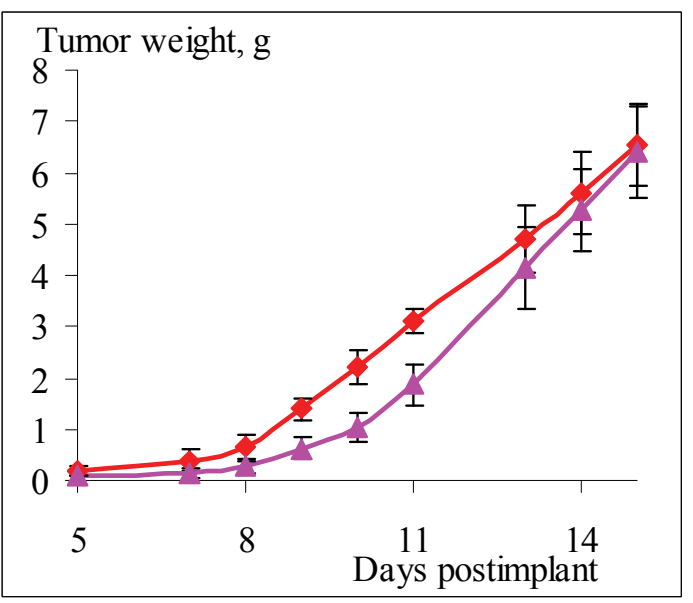

(c)

Figure 1. Antitumor activity of Argacryl (a) Auracryl, (b) Platacryl, (c) against Lewis lung carcinoma(intraperitoneal administration of compounds, 5 times, days 1-5); 1-control, 2-corresponding compound; Argacryl-2 mg/kg/day, Auracryl-10 mg/kg/day, Platacryl-4 mg/kg/day

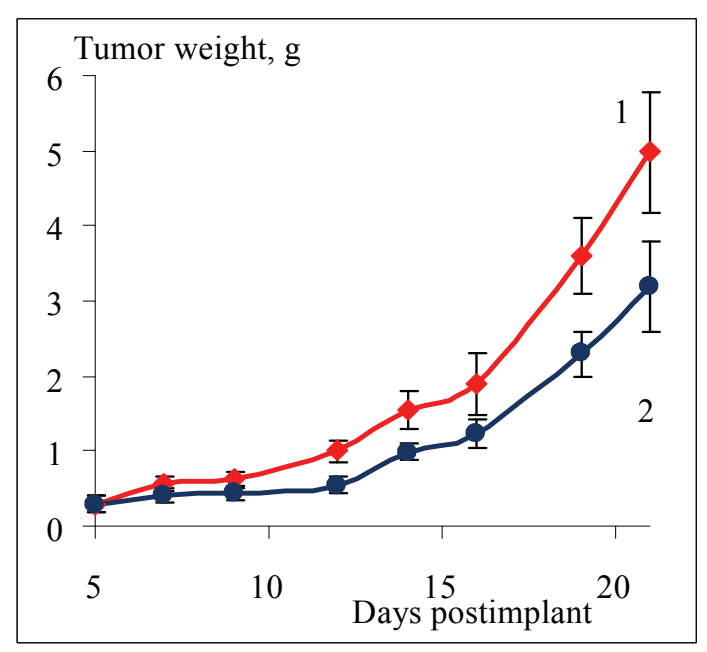

(a)

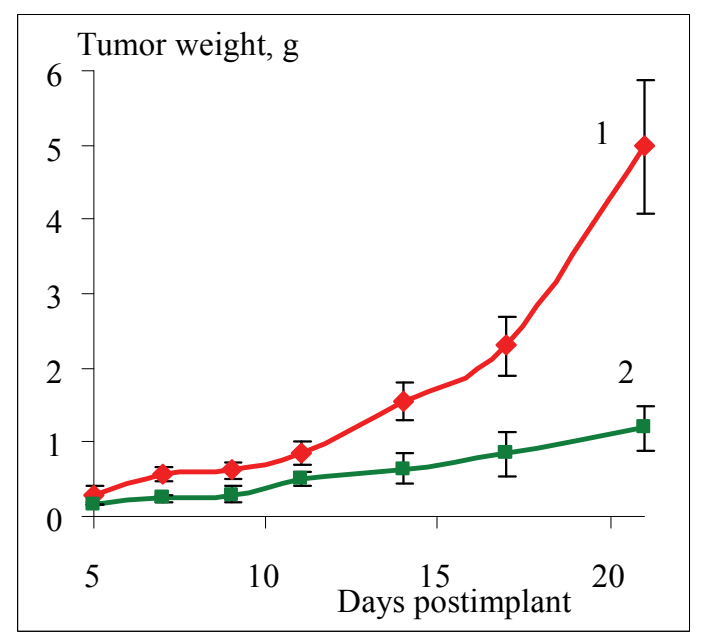

(b)

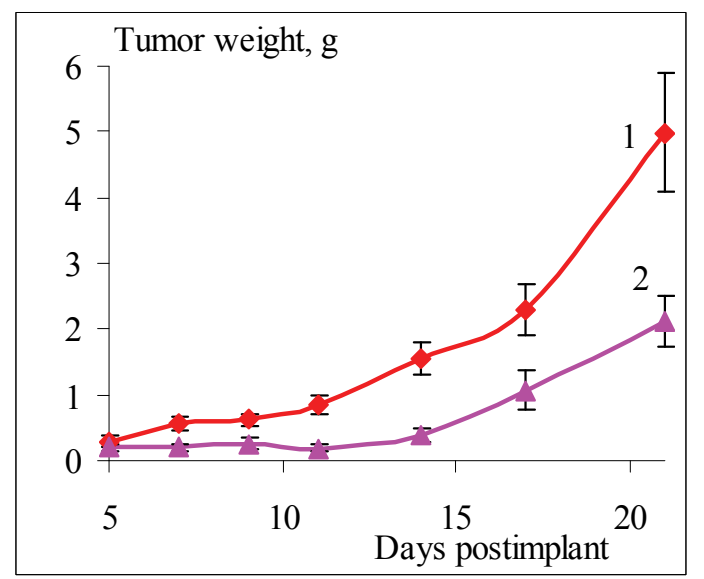

(c)

Figure 2. Antitumor activity of Argacryl (a) Auracryl, (b) Platacryl, (b) against Acatol adenocarcinoma (intraperitoneal administration of compounds, 5 times, days 1-5); 1control, 2-corresponding compound; Argacryl-1 mg/kg/day, Auracryl-10 mg/kg/day, Platacryl-4 mg/kg/day 
Table 2. Antitumor activity of polymetalacrylates (PMA) against Lewis lung carcinoma (BDF ${ }_{1}$ mice)

\begin{tabular}{|c|c|c|c|c|c|c|}
\hline \#\# & PMA & $\begin{array}{l}\text { Daily dose } \\
\text { (mg/kg) }\end{array}$ & $\begin{array}{c}\text { The mean tumor } \\
\text { weight }(\mathrm{g}) \\
\mathbf{P} \pm \mathrm{SD}\end{array}$ & $\begin{array}{c}\text { Day } \\
\text { after tumor } \\
\text { transplantation }\end{array}$ & $\begin{array}{l}\text { The coefficient of the tumor } \\
\text { growth inhibition } \\
\text { TGI, \% }\end{array}$ & $\begin{array}{c}\text { Fo.001-criterion signifi- }_{\text {cance test }} \\
\text { cat } \\
\left(f_{1}=15 ; f_{2}=11\right)\end{array}$ \\
\hline 1 & Liacryl & 10 & $6.5 \pm 0.4$ & 15 & 1 & - \\
\hline 2 & Rubacryl & 2 & $4.3 \pm 1.1$ & 15 & 35 & - \\
\hline 3 & Cesacryl & 2 & $6.6 \pm 1.1$ & 15 & 0 & - \\
\hline 4 & Licuacryl & 4 & $5.0 \pm 1.1$ & 15 & 24 & - \\
\hline 5 & Mangacryl & 5 & $6.6 \pm 1.3$ & 15 & 0 & - \\
\hline 6 & Feracryl & 20 & $5.4 \pm 0.8$ & 15 & 18 & - \\
\hline 7 & Nicacryl & 2 & $6.3 \pm 1.9$ & 15 & 5 & - \\
\hline 8 & Palladacryl & 2 & $6.3 \pm 1.4$ & 15 & 5 & - \\
\hline 9 & Platacryl*) & 4 & $1.9 \pm 0.3$ & 11 & $40 *)$ & $5.44>4.25$ \\
\hline 10 & Argacryl & 2 & $0.7 \pm \mathbf{0 . 3}$ & 15 & 90 & $7.10>4.25$ \\
\hline 11 & Auracryl*) & 10 & $1.2 \pm 0.3$ & 11 & $60 *)$ & $5.44>4.25$ \\
\hline 12 & Ziacryl & 1 & $5.4 \pm 1.2$ & 15 & 18 & - \\
\hline \multirow[t]{3}{*}{13} & Cadacryl & 5 & $4.6 \pm 1.2$ & 15 & 31 & - \\
\hline & Control*) & - & $3.1 \pm 0.7$ & 11 & - & - \\
\hline & Control & - & $6.6 \pm 0.8$ & 15 & - & - \\
\hline
\end{tabular}

Compounds were injected $\mathrm{i} / \mathrm{p}$, five times, every day starting from the next day after tumor transplantation.

*) The coefficient of the tumor growth inhibition (TGI, \%) for platacryl and auracryl was evaluated on the $11^{\text {th }}$ day after tumor transplantation, for all other agents - on the $15^{\text {th }}$ day after tumor transplantation.

Table 3. The influence of polymetalacrylates (PMA) upon the mean life-span $(\Delta \tau, \%)$ of animals with Lewis lung carcinoma (BDF 1 mice)

\begin{tabular}{|c|c|c|c|c|}
\hline$\#$ & PMA & Daily dose (mg/kg) & $\begin{array}{l}\text { The mean life-span of } \\
\text { mice (days) } \tau \pm \text { SD }\end{array}$ & $\begin{array}{l}\text { The change of the mean life-span of treated mice in } \\
\text { compare to control }(\Delta \tau, \%)\end{array}$ \\
\hline 1 & Liacryl & 10 & $30.8 \pm 5.9$ & 23 \\
\hline 2 & Rubacryl & 2 & $34.8 \pm 2.1$ & 39 \\
\hline 3 & Cesacryl & 2 & $32.3 \pm 1.5$ & 29 \\
\hline 4 & Licuacryl & 4 & $25.8 \pm 2.6$ & 3 \\
\hline 5 & Mangacryl & 5 & $30.2 \pm 2.5$ & 20 \\
\hline 6 & Feracryl & 20 & $32.8 \pm 4.5$ & 31 \\
\hline 7 & Nicacryl & 2 & $25.0 \pm 5.8$ & 0 \\
\hline 8 & Palladacryl & 5 & $24.7 \pm 2.5$ & 0 \\
\hline 9 & Platacryl & 4 & $31.3 \pm 4.2$ & 25 \\
\hline 10 & Argacryl & 2 & $36.5 \pm 2.6$ & 46 \\
\hline 11 & Auracryl & 10 & $30.0 \pm 4.3$ & 20 \\
\hline 12 & Ziacryl & 1 & $24.8 \pm 2.6$ & 0 \\
\hline \multirow[t]{2}{*}{13} & Cadacryl & 5 & $38.3 \pm 1.2$ & 53 \\
\hline & Control & - & $25.0 \pm 2.8$ & - \\
\hline
\end{tabular}


Table 4. Antitumor activity of polymetalacrylates against Acatol adenocarcinoma (Balb/c mice)

\begin{tabular}{|c|c|c|c|c|c|}
\hline \#\# & PMA & Daily dose (mg/kg) & $\begin{array}{l}\text { The mean tumor weight (g) } \\
\qquad \mathbf{P} \pm \text { SD }\end{array}$ & $\begin{array}{c}\text { The coefficient of the tumor } \\
\text { growth inhibition } \\
\text { TGI, \% }\end{array}$ & $\begin{array}{c}\mathbf{F}_{0.001} \text {-criterion significance } \\
\quad \text { test }\left(f_{1}=15 ; f_{2}=11\right)\end{array}$ \\
\hline 1 & Liacryl & 10 & $3.6 \pm 1.7$ & 28 & - \\
\hline 2 & Rubacryl & 2 & $3.2 \pm 1.2$ & 36 & - \\
\hline 3 & Cesacryl & 2 & $4.4 \pm 1.8$ & 12 & - \\
\hline 4 & Licuacryl & 4 & $4.1 \pm 2.6$ & 18 & - \\
\hline 5 & Mangacryl & 5 & $4.7 \pm 1.5$ & 7 & - \\
\hline 6 & Feracryl & 20 & $4.9 \pm 1.5$ & 1 & - \\
\hline 7 & Nicacryl & 2 & $5.1 \pm 1.2$ & 0 & - \\
\hline 8 & Palladacryl & 2 & $4.8 \pm 0.6$ & 0 & - \\
\hline 9 & Platacryl & 4 & $2.1 \pm 0.4$ & 58 & $5.06>4.25$ \\
\hline 10 & Argacryl & 2 & $3.2 \pm 0.4$ & 36 & $5.06>4.25$ \\
\hline 11 & Auracryl & 10 & $1.2 \pm 0.3$ & 76 & $9.00>4.25$ \\
\hline 12 & Ziacryl & 1 & $3.5 \pm 1.5$ & 30 & - \\
\hline \multirow[t]{2}{*}{13} & Cadacryl & 5 & $5.2 \pm 1.3$ & 0 & - \\
\hline & Control & - & $5.0 \pm 0.9$ & - & - \\
\hline
\end{tabular}

Compounds were injected $\mathrm{i} / \mathrm{p}$, five times, every day starting from the next day after tumor transplantation.

The coefficient of the tumor growth inhibition TGI, \% was evaluated on the $21^{\text {th }}$ day after tumor transplantation.

lished. Thus, these compounds may be recommended for the further advanced experimental studies as potential antitumor agents.

\section{REFERENCES}

[1] D. B. Korman, "Foundations of the Anticancer Chemotherapy," Practical Medicine, Moscow, 2006, p. 503.

[2] M. G. Voronkov, A. S. Kogan, L. M. Antonik, et al., "Antimicrobial and Hemostatic Actions of Silver Derivatives of Polyacrylic Acid," Chemical Pharmaceutical Journal, Vol. 35, No. 9, 2001, pp. 19-20.

[3] M. G. Voronkov, L. M. Antonik, K. A. Abzaeva, et al., "Antibacterial and Hemostatic Properties of Silver Derivatives of Polyacrylic Acid," Chemical Pharmaceutical Journal, Vol. 36, No. 2, 2002, pp. 27-29.

[4] M. G. Voronkov, K. A. Abzaeva, L. V. Zhilitskaya and L. A. Ostrovskaya, et al., "Antitumor Agent Referring to the Group of Metalorganic Derivatives of Polyacrylic Acid", Patent of the RF, Bulletin of Inventions, No. 31, 2009.

[5] K. A. Abzaeva, M. G. Voronkov, L. V. Zhilitskaya, et al., "Incomplete Zinc Salt of Polyacrylic Acid, its Synthesis and its Antiseptic, Hemostatic and Wound Healing Actions at External Administration," Patent of the RF, Bulletin of Inventions, No. 2, 2008.

[6] K. A. Abzaeva, M. G. Voronkov and L. V. Zhilitskaya, "Pharmacological Activity of Ziacryl, a Zinc Salt of Polyacrylic Acid," Chemical Pharmaceutical Journal, Vol. 43, No. 12, 2009, pp. 68-71.

[7] K. A. Abzaeva, M. G. Voronkov and L. V. Zhilitskaya,
"Pharmacological Properties of Poly (Zincacrylate) Ziacryl," Doklady Biological Sciences (Biological Sciences Reports), Vol. 424. No. 1, 2009, pp. 135- 137.

[8] N. O. Jarosh, K. A. Abzaeva and L. V. Zhilitskaya, "Pharmacological Properties of Metal Derivatives of Polyacrylic Acid," Bulletin of East-Siberian Research Centre, Irkutsk, Vol. 60, No. 2, 2008, pp. 120.

[9] E. V. Anufrieva, R. A. Gromova, V. B. Luschik, et al., "Influence of Aluminium Salts on Structure Formation in Polymer Solutions," Polymer Science, Series B, Vol. 38, No. 9, 1996, pp. 1614-1616.

[10] K. A. Abzaeva, M. G. Voronkov and V. A. Lopyrev, Polymer Science, Series B, Vol. 39, No. 11-12, 1997, pp. 409-428.

[11] M. G. Voronkov, et al., "Synthetic Method for Salt of Polyacrylic Acid," Bulletin of Inventions, No. 46, 1979, p. 223.

[12] U. F. Krilov, "Register of medicines of Russia," Inpharmchim (Inpharmchemistry), Moscow, 1993, p. 1006.

[13] M. G. Voronkov, et al., "Device for the Synthesis of Iron Containing Polyacrylic Acid," Patent of the RF, Bulletin of Inventions, No. 16, 1998.

[14] M. G. Voronkov, V. A. Lopiriov and L. M. Antonic, et al., "Argacryl as a New Antiseptic and Hemostatic Preparation," Patent of the RF, Bulletin of Inventions, No. 1, 2004, p. 781 .

[15] A. M. Bhagwat, S. Save, S. Burli and S. G. Karki, Indian Journal of Pathology and Microbiology, Vol. 44, No. 4, 2001, pp. 431-433. 
[16] M. D. Mashkovskii, "Medicines. Manual for Doctors", The New Wave, Moscow, Vol. 2, 2003, p. 608.

[17] "The Application of the Silver Drugs in Medicine," In: E. M. Blagitko Ed., ZAO "Vector-Best", Novosibirsk, 2003, p. 115 .

[18] I. A. Efimenko, "Bio-coordination Chemistry of Platinum Metals - The Base for the Design and Development of Drugs," Coordination Chemistry, Vol. 24, No. 4, 1998, p. 282.

[19] M. Gielen and E. R. T. Tiekink, "Metallotherapeutic Drugs and Metal-Based Diagnostic Agents," John Wiley and Sons, Ltd., Chichester, 2005, p. 598.

[20] R. P. Evstigneev and V. P. Pchelkin, "Catalytic and Biological Activity of Organic Complexes of Noble Metals," Chemical Pharmaceutical Journal, Vol. 37, No. 11, 2003, pp. 9-13.

[21] E. M. Treschalina, O. S. Jukova, G. K. Gerasimova, et al., "Guide of the Experimental (Preclinical) Study of Pharmacological Compounds," In: R. U. Habriev Ed., Medicine, Moscow, 2005, pp. 637-651.

[22] N. T. J. Bailey, "Statistical Methods in Biology," Publishing House of Foreign Literature, Moscow, 1962, p. 251. 